\title{
Tolerância e neutralidade na reflexão contemporânea sobre a justiça
}

Tolerance and neutrality in contemporary thought on justice

Este artigo tem por propósito discutir, à luz da teoria política normativa recente, em especial a que tem por o foco a temática da justiça, as noções de tolerância e de neutralidade, ambas centrais à reflexão sobre as sociedades democráticas contemporâneas. Ainda que incorporadas ao vocabulário político do nosso tempo, tolerância e neutralidade são ideias mutuamente intricadas e complexas, desafiando, do ponto de vista prático e teórico, a imaginação daqueles que se debruçam sobre o problema da coexistência humana em sociedades pluralistas - isto é, divididas quanto ao que vem a ser valioso moralmente no plano individual e no que concerne aos arranjos sociais coletivos.

A questão da tolerância está vinculada à própria emergência do mundo ocidental moderno. Um dos modos clássicos de datar a modernidade consiste em apontar como um de seus vetores históricos de deflagração a Reforma e as subsequentes guerras religiosas - fenômenos que marcaram, nos séculos XVI e XVII, o fim de uma longa constelação cultural, o Ocidente medieval, que se pretendia uno em termos morais e éticos.

A fratura religiosa - e de concepções do bem, em sentido ainda mais abrangente - se consolidou e aprofundou com o avanço e a cristalização das economias capitalistas de mercado, da ciência empírica pós-baconiana e das instituições do Estado nacional, outros vetores fundamentais do pe-

É doutor em Ciência Política pela Universidade de São Paulo (São Paulo, SP).E-mail: seferrazz@uol.com.br. 
ríodo moderno, bem como com a ascendência do iluminismo e das visões seculares, marcando de modo permanente a fisionomia do Ocidente e de todas as culturas sob sua influência. Nesse sentido, o problema da tolerância, premente em contextos sociais de múltiplas e conflitantes lealdades últimas, consolidou-se como um dos eixos centrais da própria política na modernidade, tanto na sua dimensão reflexiva como na qualidade de exigência prática.

Talvez não seja inócuo lembrar, também, que as experiências totalitárias e de conflitos mundiais generalizados no século XX - que contribuíram, ao lado de outros fatores, para desacreditar visões redentoras e milenaristas da história e dos indivíduos - lançaram renovadas luzes sobre a natureza não contingente das diferenças, de variada ordem, que estruturam a nossa experiência individual e coletiva. Por último, as múltiplas facetas de um mundo caracterizado pelo que se convencionou chamar de multiculturalismo potencializam, nos tempos presentes, os dilemas envolvidos na estruturação democrática de sociedades crescentemente confrontadas com práticas culturais diversificadas e, em muitos casos, conflitantes quanto a valores éticos e morais.

É, portanto, a natureza permanente da diversidade e do conflito, tão reiterada pela história, que atualiza e empresta relevância ao estudo da tolerância e ao exame da noção correlata da neutralidade, esta última entendida como exigência endereçada às instituições políticas da sociedade. Trata-se, neste texto, de examiná-las à luz de considerações normativas, buscando articular o tipo de compreensão desses ideais que se revele compatível com as exigências de igualdade e liberdade impostas às nossas sociedades como projetos de coexistência democrática.

Para levar à frente a tarefa proposta, o artigo está dividido em onze intertítulos, além desta parte introdutória. Inicialmente, examino o conceito de tolerância, suas distintas dimensões e exigências lógicas, transitando, em seguida, para concepções normativamente mais densas da noção. Em seguida, desenvolvo argumentos que indicam a maior adequação, no contexto de sociedades pluralistas, da concepção de tolerância como "respeito mútuo". Para detalhar os contornos dessa concepção de tolerância, introduzo, na reflexão, a noção de neutralidade, referida às instituições políticas e entendida como ideia correlata ao próprio valor da tolerância. Feito isso, assinalo que a tolerância como "respeito mútuo", um ideal regulatório, mostra-se compatível com diferentes modelos normativos de justificação. Nesse sentido, argumento 
pela rejeição de tentativas de ancorar a tolerância (e a neutralidade) em razões elas próprias neutras, do ponto de vista moral, defendendo a inevitabilidade, nessa matéria, de hard-choices. Discuto, então, já na parte final do trabalho), dois modelos normativos presentes na literatura (centrados, respectivamente, nos valores da autonomia e da justificação razoável) e sugiro que, em certa medida, alguns elementos extraídos do liberalismo rawlsiano podem configurar uma síntese inclusiva dos dois modelos normativos esboçados.

\section{Tolerância: conceito e concepções}

Entendida como princípio político e regra vinculante válida para uma sociedade, a tolerância, nos termos de Galeotti (2008, p. 564), é a característica que abre espaço para a coexistência pacífica de indivíduos e grupos que sustentam crenças, convicções e estilos de vida diversos, diferindo, muitas vezes de modo profundo e inconciliável, em suas concepções morais, religiosas e filosóficas - tanto sobre o que vem a ser valioso do ponto de vista individual como da ótica da organização da vida em comum. As circunstâncias que requerem a tolerância, portanto, caracterizam-se não só pela existência de diferenças, mas por diferenças que, de forma potencial ou efetiva, introduzem tensões e conflitos nos arranjos societários.

Por outro lado, do ponto de vista individual, a noção de tolerância apresenta, de imediato, um desafio: o de nos obrigar a colocar em xeque as nossas próprias convicções morais de modo a conter ou restringir, em nome de razões igualmente morais, as implicações plenas de nosso ponto de vista original sobre alguma questão ética. Em outras palavras, tolerar significa qualificar as consequências de uma crença que sustentamos, aceitando, com reservas, comportamentos, práticas ou pontos de vistas com os quais, em algum grau, estamos em desacordo ${ }^{1}$. Como sugere Thomas Scanlon (2003, p. 187-8), a atitude de tolerância envolve um comportamento que é intermediário entre a plena aceitação e a oposição irrestrita. Mais especificamente, o que esse autor chama de casos "puros" de tolerância não se confunde com expedientes para lidar com imperfeições da nossa natureza (preconceitos, bias, autointeresse etc.), conquanto aqueles se façam necessários dada a persistência dessas falhas. A tolerância, diferentemente, vincula-se, aqui,

Nos termos de Rainer Forst (2007, p. 1), "o termo tolerância (...) geralmente se refere à aceitação condicional e/ou a não interferência com crenças, ações e práticas consideradas erradas mas 'toleráveis"', no sentido de que não são vistas como justificáveis ações voltadas a sua proibição ou restrição. 
ao desacordo razoável, compatível com o respeito mútuo entre os que divergem. Trata-se, por conseguinte, de uma noção de tolerância adequada para lidar com as circunstâncias do pluralismo associadas, de um modo não contingente, à cultura pública das sociedades democráticas contemporâneas, em especial com o desacordo derivado do que John Rawls (1993, p. 54-8; 1999, p. 475-8) chamou de "limites da capacidade de juízo ou julgamento" (“burdens of judgment") ${ }^{2}$.

\section{O conceito de tolerância e seus componentes: objeção, aceitação e rejeição}

Uma atenção ao conceito de tolerância propicia um entendimento mais acurado de seus contornos. Para isso, lanço mão da análise empreendida por Rainer Forst (2007). Para ele, compreender a ideia de tolerância exige demarcar seus componentes específicos, consubstanciados em três dimensões implicadas na noção, a saber, objeção, aceitação e rejeição. O primeiro componente remete ao fato de que é essencial ao conceito de tolerância a natureza objetável das crenças ou práticas que são objeto de tolerância. Em algum sentido importante, de modo que a atitude em questão não se confunda com a indiferença, tais comportamentos ou convicções são vistos como suscetíveis à crítica ou censura, quaisquer que sejam os fundamentos últimos destas, desde que razoáveis em um sentido mínimo (Forst, 2007, p. 2; Galeotti, 2008, p. 565)3 . Por outro lado, essa dimensão de objeção necessita ser contrabalançada ou restringida pelo que Forst chama de componente de aceitação, o qual, embora sem remover no todo o julgamento negativo, oferece certas razões positivas vistas como suficientes para tornar

Esses limites respondem pelo fato de que muitos dos nossos mais importantes julgamentos são feitos sob condições "que tornam extremamente improvável que pessoas conscienciosas e plenamente razoáveis, mesmo após discussão livre, possam exercer seus poderes da razão de modo a chegar todas às mesmas conclusões" (Rawls, 1999, p. 478). O conceito de Scanlon parece-me plenamente consonante com essa perspectiva. Tratarei, adiante, em mais detalhes, do referido conceito rawlsiano, voltando, também, à contribuição de Scanlon. A tradução no texto para a expressão "burdens of judgment" acompanha solução apresentada por Álvaro de Vita.

Para serem consideradas razoáveis, no sentido mínimo referido, as objeções não podem estar baseadas, por exemplo, em preconceitos irracionais ou em hostilidade gratuita, segundo padrões culturais amplamente consensuais nas sociedades contemporâneas comprometidas com valores liberais e democráticos (Forst, 2007, p. 2). Nesse sentido, a objeção de um racista não tem valor, nem dele é demandado que se comporte com tolerância, mas que modifique suas crenças ou, no mínimo, que não viole prerrogativas alheias a partir de ações baseadas no preconceito. 
moralmente inadequada a oposição irrestrita ao objeto em foco ${ }^{4}$. Para Forst, apareceria aqui, aparentemente, um paradoxo, porquanto, à luz das razões de aceitação, conclui-se que seria errado, do ponto de vista moral, reprimir o que também é considerado moralmente como erro. Trata-se, na verdade, como dirá o próprio autor em foco, não de uma real antinomia, mas de um escalonamento ou de uma hierarquização de diferentes tipos de razões morais (2007, p. 2-3), algumas das quais podem, em princípio, sobrepujar outros argumentos, o que é comum não só na discussão do tema da tolerância, mas em qualquer exercício teórico ou filosófico de cunho normativo. Por fim, um terceiro componente da ideia de tolerância aponta para a necessidade da demarcação dos limites do que pode ser tolerado. Esse limite, do ponto de vista lógico, assinala Forst, é alcançado quando são mais poderosas as razões morais para a oposição irrestrita do que os argumentos conducentes à aceitação. Essa terceira dimensão da tolerância materializaria o componente da rejeição, ingrediente também inerente à ideia em foco.

Do que foi dito, resulta que o conceito de tolerância envolve duas fronteiras que demarcam um triplo espaço normativo (Forst, 2007, p. 2). A primeira delas separa o espaço normativo onde estão contidas as práticas e as crenças em congruência com a nossa postura moral (ou com a de algum tipo de regime coletivo de tolerância) daquele outro território onde circulam os comportamentos e as convicções perante os quais alguém ou algum arranjo nutre reservas, considerando-as, não obstante as restrições referidas, passíveis de tolerância. A segunda fronteira, por seu turno, diferencia esse último espaço do território do que é irrestritamente rejeitado ou excluído, demarcando os limites externos do regime de tolerância ${ }^{5}$.

Com exceção da breve passagem mencionada anteriormente, alusiva à noção scanloniana de tolerância "pura", que já sugere um substrato normativo específico, suficiente, quando desenvolvido, para emprestar um contorno mais nítido à ideia em foco, as considerações tanto de Galeotti como de Forst alinhavadas até aqui ajudam a apresentar o conceito de tolerância, mas ainda não nos fornecem concepções densas da noção. Ou seja, não possuímos ainda argumentos morais capazes de fundamentar razões substantivas para

Esse componente de aceitação está, obviamente, ausente em práticas hoje universalmente condenadas, a exemplo do racismo, da tortura e da escravidão, o que as torna, moralmente, objeto de irrestrita rejeição e não de tolerância (Galeotti, 2008, p. 565-6; Scanlon, 2003, p. 187).

5 No contexto de uma crítica da análise da tolerância feita por autores vinculados ao "liberalismo perfeccionista", reaparece em Galeotti a ideia de duas fronteiras e três espaços normativos (2008, p. 567-8). 
a objeção, aceitação e rejeição, de modo que possamos avaliar, por exemplo, regimes concretos de tolerância. Sabemos algo sobre a estrutural conceitual ou lógica envolvida na ideia de tolerância, mas não temos até aqui argumentos sobre que formas de tolerância seriam mais ou menos defensáveis à luz, igualmente, de determinados pressupostos normativos. É isso que conduz Forst a afirmar que o conceito de tolerância é normativamente dependente, demandando recursos normativos adicionais para ganhar conteúdo substantivo $(2007, \text { p. } 3)^{6}$.

\section{Concepções de tolerância}

Para emprestar conteúdo substantivo à noção, Forst (2007, p. 3-6) vai identificar quatro concepções da tolerância historicamente desenvolvidas no âmbito do pensamento político ocidental. Para ele, essas diferentes compreensões a respeito da tolerância não representam uma sucessão histórica linear de visões sobre a temática; distintamente, para Forst essas concepções coexistiram e podem ainda coexistir no âmbito de uma mesma sociedade, de modo que "conflitos sobre o significado da tolerância podem ser também entendidos como conflitos entre essas concepções" (2007, p. 3). Passo à apresentação das concepções ${ }^{7}$.

A primeira delas centra-se na ideia de permissão. Nesse caso, uma maioria ou uma autoridade central se relaciona, de cima para baixo, com uma ou várias minorias vistas como "dissidentes" em relação aos padrões dominantes (culturais, ideológicos, religiosos, morais etc.). A autoridade "permite" ou "tolera" a existência da minoria que, em troca, aceita a posição de superioridade dos que controlam o poder, sendo as condições dessa relação estipuladas, em essência, pelos segmentos dominantes da sociedade; esses termos, em geral, de modo mais ou menos formal, explicitam uma relação hierárquica entre maioria e minorias, sendo inferior o status público, político e jurídico destas últimas. A relação de tolerância, aqui, baseia-se tanto em razões pragmáticas (manutenção da ordem) como em considerações de

\footnotetext{
Sobre o mesmo ponto, assinalando a precedência de argumentos normativos sobre a análise conceitual ou lógica, ver Waldron (1993, p. 153).

Há certo paralelismo entre a visão de Forst sobre concepções de tolerância e o modo como Michael Walzer (1999) explora a mesma temática; no caso desse último autor, encontramos a associação entre regimes específicos de tolerância vigentes na história - materializados em arranjos institucionais específicos - e determinadas visões e compreensões normativas da questão. Sobre um contraste entre regimes tolerância liberais e não liberais, ver também Kymlicka (1992b).
} 
princípio (as quais condenam a repressão a crenças e práticas solidamente instaladas entre parcelas da população, em muitos casos desde tempos imemoriais). Resta claro que, nessa interpretação da ideia de tolerância, a autoridade retém, legitimamente, segundo os arranjos em vigor, o poder de interferir nas práticas da minoria, concedendo-lhe, porém, uma existência consentida. Essa ideia de tolerância, caracterizada pela noção de concessão ou permissão condicional, é exemplificada por vasto número de situações históricas; no período moderno, por vários arranjos emergentes na esteira da Reforma e das guerras religiosas, entre os quais o Edito de Nantes, de 1598 (Forst, 2007, p. 4).

A segunda concepção de tolerância traz ao primeiro plano a ideia de coexistência (Forst, 2007, p. 4). Compartilhando características da primeira perspectiva (estratégia de minimização de conflitos e manutenção da ordem, espaço para a persecução dos próprios fins, ainda que com severas qualificações etc.), essa segunda visão se diferencia, no entanto, pelo tipo de relação entre os segmentos sociais envolvidos. Em vez de hierarquia e verticalidade, temos aqui uma relação horizontal, lastreada no compromisso recíproco, em que diferentes grupos sociais são simultaneamente sujeito e objeto de tolerância. Um pressuposto da emergência da tolerância como coexistência é, frequentemente, a exaustão advinda de um longo período de conflito irrestrito bem como a percepção, pelas partes em disputa, de certa equivalência relativa de forças. Ainda que prossigam profundamente divididos sobre questões vistas como essenciais (o exemplo religioso vem a ser o processo clássico na história do desenvolvimento moderno das formas de tolerância no Ocidente $)^{8}$, os diferentes segmentos terminam por cristalizar a percepção de que um acordo é o melhor resultado disponível nas circunstâncias. Sendo a coexistência um second best, do ponto de vista dos grupos envolvidos, é inerente a essa interpretação da tolerância o ônus da instabilidade, uma vez que a reprodução continuada no tempo desse modus vivendi depende da contingente persistência de uma correlação de forças vista como "equilibrada" pelos vários interessados.

A terceira concepção difere substantivamente das duas primeiras, sublinhando a ideia de respeito mútuo entre os diversos sujeitos (e objetos) da

A importância da Reforma e de seus desdobramentos, nos séculos XVI e XVII, para a emergência das formas modernas de tolerância e na origem da própria tradição política liberal, é enfatizada por Rawls (1993, p. xxv-xxvi; 1999, p. 388-414, 421-48). Sobre o ponto, ver também Kymlicka (1992b). 
tolerância. Aqui reencontramos a família das concepções de tolerância no interior das quais se insere a noção de tolerância razoável referida anteriormente. Nos termos de Rainer Forst,

embora [os diferentes cidadãos] divirjam fundamentalmente em suas crenças éticas a respeito dos modos de vida verdadeiros e bons e em suas práticas culturais, [eles] (...) reconhecem um ao outro como iguais do ponto de vista moral e político no sentido de que (...) [a estrutura comum organizativa da vida social sob a qual todos são obrigados a viver] deve - na medida em que estejam em jogo questões de direitos e de liberdades e a distribuição de recursos - ser guiada por normas que todas as partes possam igualmente aceitar e que não favoreçam nenhuma comunidade cultural ou ética específica (2007, p. 4-5) .

Trata-se de uma ideia de tolerância que vai além de um modus vivendi, posto que é regulada por um ideal de padrão público de justiça legitimado por cidadãos que, embora divididos quanto às compreensões do bem, se reconhecem reciprocamente, no plano político e moral, como iguais, e estão empenhados em uma convivência cidadã pautada por critérios normativos de mutualidade e reciprocidade, os quais excluem o privilégio e a discriminação arbitrária no plano institucional.

Uma quarta e última concepção se funda na noção de estima e demanda mais do que o simples "respeito mútuo" entre os concidadãos, requerendo, também, algum tipo de estima ética recíproca. Aqui, segundo Forst (2007, p. 5), tolerância significa não apenas o reconhecimento da igualdade moral e política dos que se vinculam a crenças e práticas culturais distintas das nossas, mas também a expressa valorização dessas outras concepções do bem, portadoras de aspectos atrativos eticamente, conquanto, por determinadas razões, vistas como menos adequadas do que nossas próprias doutrinas e formas de vida.

Interessa, agora, indagar qual ou quais das concepções esboçadas de tolerância é a mais atrativa do ponto de vista moral para as sociedades democráticas contemporâneas. Para alinhavar respostas à questão, é necessário um maior esforço de argumentação normativa - tanto para justificar

Forst subdivide essa concepção em dois modelos específicos ("igualdade formal" e "igualdade qualitativa"), mostrando as distintas implicações de cada um no tratamento de problemas vinculados ao multiculturalismo (2007, p. 5). 
moralmente determinada concepção de tolerância priorizada como para compreender melhor o núcleo de exigências normativas endereçadas às sociedades contemporâneas comprometidas com valores como os da igualdade e da liberdade, uma vez que as duas questões caminham juntas. É disso que vai tratar a próxima seção do trabalho.

\section{Tolerância, neutralidade estatal e justificação moral}

Se aceitarmos, como premissa axiológica, a ideia da igualdade moral dos cidadãos e o pluralismo das suas concepções do bem como pilares centrais do projeto democrático e liberal contemporâneo - nos termos sustentados por boa parte da filosofia política normativa recente, a qual ganhou grande ímpeto a partir da publicação de obras como A theory of justice (1971), de John Rawls -, teremos uma base inicial de argumentos para destacar, dentre as concepções de tolerância esboçadas, a noção centrada na ideia de "respeito mútuo", a qual se afigura consonante com as exigências morais hoje endereçadas as nossas sociedades ${ }^{10}$.

As demais concepções tomam por pressuposto a desigualdade moral, política e/ou jurídica entre grupos ou indivíduos, permitindo relações hierárquicas ou verticais (permissão), convivem com limites arbitrários e voláteis para o exercício da tolerância, ressentindo-se de instabilidade e precariedade de garantias (coexistência) ou embutem exigências ambiciosas que tornam altamente provável o estreitamento do espaço societário de tolerância, com os correlatos ônus de sectarização (estima).

A tolerância entendida como "respeito mútuo" pode, porém, ser justificada de variadas formas, implicando diferentes consequências, por exemplo, para a ação do Estado e para a própria arquitetura constitucional garantidora do valor moral em foco (Waldron, 1993, p. 151-3; Macedo, 1995). Para explorarmos esse ponto e tentarmos entender melhor os contornos da concepção de tolerância destacada, é útil introduzir a noção de neutralidade estatal, ideia correlata ao próprio valor da tolerância.

Embora remontando às clássicas preocupações liberais a respeito do secularismo e à ideia de que o Estado deve respeitar e garantir, em termos de direitos e liberdades, espaços privados onde o indivíduo está livre para perseguir seus

10 “(...) nas discussões filosóficas correntes da tolerância em sociedades multiculturais modernas, a concepção [centrada no] respeito é frequentemente vista como a mais apropriada e promissora" (Forst, 2007, p. 10). 
próprios valores religiosos e morais, a noção de neutralidade do Estado, segundo Jeremy Waldron, é um modo, relativamente recente, de expressar a histórica atitude normativa liberal frente à relação entre a autoridade pública e as crenças morais dos cidadãos (1993, p. 143-5). Nesse sentido, ainda conforme Waldron, teria sido Ronald Dworkin (2005) o primeiro teórico liberal contemporâneo a dar contornos claros à doutrina da neutralidade, em seu conhecido texto intitulado "Liberalism"11. Volto-me, portanto, para a formulação de Dworkin.

No texto em questão, o filósofo e jurista norte-americano vincula o pensamento liberal ao princípio abstrato de igual consideração e respeito, o qual deve nortear a ação do Estado frente a cada cidadão. Procurando interpretar essa (reconhecidamente controversa) exigência normativa, Dworkin chegará à ideia de neutralidade. Para ele, tratar os cidadãos como iguais exige que a autoridade se porte de forma neutra no que concerne ao "(...) que se poderia chamar de questão do viver bem” (2005, p. 285). Nesse sentido, consoante Dworkin, a neutralidade sustenta

(...) que as decisões políticas devem ser, tanto quanto possível, independentes de qualquer concepção particular do que é viver bem, ou do que dá valor à vida. Como os cidadãos de uma sociedade divergem em suas concepções, o governo não os trata como iguais se prefere uma concepção à outra, seja porque as autoridades acreditam que uma é intrinsecamente superior, seja porque uma é sustentada pelo grupo mais numeroso ou mais poderoso $(2005, \text { p. } 286)^{12}$.

Partindo dessa noção ampla de neutralidade, refratária, como se depreende da passagem transcrita, tanto ao perfeccionismo estatal como a formas utilitaristas de "welfarismo", é necessário desdobrá-la para que se delineie um esboço mais nítido desse comprometimento normativo, correlato à tolerância no sentido de respeito mútuo, sublinhado por parcela expressiva dos liberais contemporâneos.

Em primeiro lugar, a neutralidade é demandada do Estado, e a razão disso é a sua condição especial nas sociedades modernas, a saber, em termos

\footnotetext{
Publicado em A matter of principle (1985). A edição brasileira desse volume de ensaios, com o título Uma questão de princípio, foi publicada em 2005.

12 Para Will Kymlicka (1992a, p. 165), “Um aspecto distintivo da teoria liberal contemporânea é sua ênfase na'neutralidade' - a visão de que o Estado não deve premiar ou penalizar concepções particulares da boa vida, mas, distintamente, deve garantir uma estrutura neutra dentro da qual concepções do bem diferentes e potencialmente conflitantes possam ser perseguidas".
} 
weberianos, o fato de que repousa nas instituições políticas o monopólio do exercício legítimo da violência. É o vínculo, portanto, entre lei, em sentido amplo, e força que legitima a exigência de neutralidade endereçada ao Estado - quando do exercício da produção e aplicação de normas vinculantes para todo o corpo de cidadãos (Waldron, 1993, p. 154-5) ${ }^{13}$. Os ordenamentos estatais são impostos coercitivamente, qualidade que diferencia a norma jurídica perante as demais regras morais ou sociais ${ }^{14}$. O pluralismo das concepções do bem, visto, como já anotado antes, como consequência ínsita ao próprio exercício das faculdades de formação do juízo pelo cidadão em um ambiente de instituições livres (Rawls, 1993, p. 54-8; 1999, p. 474-8), e não como realidade transitória ou contingente, requer, por conseguinte, que a autoridade, ao produzir a regra legal, possa justificá-la a jurisdicionados moralmente heterogêneos, advindo daí o requerimento liberal em foco ${ }^{15}$. A neutralidade aparece, nesse sentido, como um requerimento específico à moralidade política ou como uma virtude associada ao exercício do poder político (Waldron, 1993, p. 154-5) ${ }^{16}$.

Dentro dessa perspectiva, seria absurdo e contraditório estender essa exigência para todos os indivíduos no que concerne à generalidade de seus atos, comprometimentos e escolhas (Waldron, 1993, p. 154; Mendus, 2008, p. 425-8 e 434), uma vez que a neutralidade é demandada da autoridade pública justamente como um sinal de igual respeito e consideração pela diversidade de projetos de vida e doutrinas morais objeto de adesão por parte dos cidadãos. É porque a vida social não é neutra e os cidadãos discriminam legitimamente

\footnotetext{
${ }^{13}$ Se essa neutralidade deve abranger todas as regras vinculantes produzidas pelo Estado ou apenas um seu subconjunto - aquelas que estruturam, por exemplo, o que Rawls chama de constitutional essentials e as questões de "justiça básica", sujeitas as demais apenas aos procedimentos majoritários instituídos - é, em si mesmo, um ponto de controvérsia no interior da tradição liberal contemporânea. A perspectiva rawlsiana sobre o ponto é exposta nos seus dois ensaios sobre a noção de razão pública (1993, p. 212-254; 1999, p. 573-615).

14 Eventuais regras coercitivas emergentes em decorrência da liberdade associativa ou cristalizadas em outros âmbitos não públicos são, elas próprias, reguladas direta e indiretamente pelo Estado, tanto no sentido dos limites de sua permissibilidade e aplicação, os quais devem ser congruentes com as estruturas constitucionalmente asseguradas de direitos e garantias para os cidadãos, como também no fato de que as instâncias judiciárias do aparato estatal são, em última análise, a fonte de decisão vinculante última quando emergem desacordos no âmbito associativo e em outros espaços não públicos.

15 Gerando, nas palavras de Rainer Forst, um "direito à justificação", oponível a normas éticas ou religiosas discriminatórias ou parciais (2007, p. 11).

${ }^{16}$ As características especiais associadas ao Estado, para Rawls - ou, em seus próprios termos, o "domínio especial do político" (1999, p. 482-4) -, compreendem não apenas a dimensão coercitiva assinalada no texto, mas também a "natureza fechada" das sociedades políticas no sentido de que, em que pesem os direitos migratórios, a "entrada" e a "saída" nas mesmas possuem natureza não voluntária.
} 
entre várias possibilidades valorativas - no curso das escolhas e decisões que, no conjunto, dão forma a uma trajetória individual - que o Estado deve ser neutro (Kymlicka, 1992a, p. 173).

Vistas por outro ângulo, a neutralidade estatal e a realidade agregada da heterogeneidade moral e ética dos cidadãos materializam uma espécie de "divisão moral do trabalho entre a sociedade e o indivíduo", para utilizar os termos de Thomas Nagel (1987, p. 238); nessa partilha de tarefas, às instituições cabe a sustentação das regras gerais impessoais - e, portanto, neutras - que atribuem direitos e estipulam restrições, bem como estabelecem normas básicas de equidade distributiva, ficando os indivíduos, desde que cumpram seus deveres de apoio às instituições mencionadas (Rawls, 1971, p. 114-7), liberados para conduzirem suas vidas de acordo com valores e comprometimento mais pessoais, refletindo suas escolhas e perspectivas específicas e particulares (Nagel, 1987, p. 238).

Outro ponto de preocupação entre os estudiosos vem a ser a delimitação mais precisa do tipo de neutralidade que se deve reivindicar à autoridade. Nesse sentido, quando usamos a ideia de neutralidade, estamos nos referindo, para usar a nomenclatura empregada por Will Kymlicka (1992a, p. 165-9), a uma concepção consequencial ou justificatória de neutralidade? Em outros termos, devemos cobrar neutralidade quanto aos resultados da ação estatal (neutralidade de resultados) ou nos preocupar, essencialmente, com o caráter neutro dos fundamentos dessa ação (neutralidade de justificação)?

Uma visão consequencial da neutralidade preocupa-se com as implicações da ação estatal em termos de sua incidência, mais ou menos favorável, sobre as diversas concepções do bem e formas de vida existentes. Em termos ideais, a lei - bem como quaisquer outras ações das instituições políticas centrais de uma sociedade - deve ter efeitos equilibrados sobre as diversas perspectivas éticas e morais em circulação. Assim, a ação estatal, para satisfazer os critérios de neutralidade, não pode produzir implicações que favoreçam, digamos, estilos de vida hedonistas em detrimento de valores cristãos tradicionais (Waldron, 1993, p. 150). Uma postura consequencial exige, portanto, a rigor, que políticas públicas, disposições constitucionais e legais, interpretações judiciais da lei e mesmo atos administrativos não tragam vantagens relativas a determinadas formas de existência, ou a certas posturas ético-morais, em prejuízo de outras. Se há competição e conflito entre concepções do bem, conformando um mercado de ideias e de cultura, em 
sentido amplo (Kymlicka, 1992a), cumpriria ao Estado não gerar desequilíbrio quanto aos seus resultados.

A outra concepção - justificatória ou centrada nas intenções ou razões admite que a ação estatal, em sentido amplo, inevitavelmente trará efeitos diferenciais sobre estilos de vidas diversos, somando-se assim a outras correntes e tendências em vigor na estrutura cultural mais ampla de uma sociedade, terminando por abrir, por conseguinte, mais espaço para a sobrevivência de determinadas concepções morais do que para outras. O que ela veda, contudo, é que a autoridade pública deve ter como propósito essa discriminação, excluindo, desse modo, quaisquer medidas governamentais - em sentido lato, lastreadas, em última análise, na máquina coercitiva estatal - cuja meta seja o benefício desigual de determinadas posturas valorativas existenciais. Dada a dificuldade mais ou menos óbvia de isolar razões efetivas ou intenções subjacentes a determinada norma estatal ${ }^{17}$, talvez a melhor forma de entender essa concepção seja considerá-la como um parâmetro normativo de restrição nas razões suscetíveis de emprego na (re)construção de alguma regra legal ou de alguma ação estatal com repercussões no terreno aqui discutido; essas devem ser razões aceitáveis ou, no mínimo, não suscetíveis de objeção razoável do ponto de vista de cada um dos cidadãos sujeitos à norma, titulares de um direito (recíproco) à justificação (Waldron, 1993, p. 151; Forst, 2007, p. 11) ${ }^{18}$. A rigor, na perspectiva de uma concepção de justiça, em sentido amplo, esse teste de razoabilidade se aplica, mais compreensivamente, ao próprio arranjo institucional básico (as instituições políticas, sociais e econômicas) sob o qual os cidadãos devem conduzir suas vidas e, naturalmente, às suas normas e ações, objeto de preocupação específica do texto.

Entre os teóricos liberais contemporâneos, há uma clara tendência a alinhar-se com a concepção centrada em razões ou na justificação, tanto por motivos morais como por motivos práticos ${ }^{19}$. Do ponto de vista moral, assinala-se que o objetivo da neutralidade é assegurar um ambiente plural de tolerância onde, dentro de certos limites, e nos termos das liberdades civis e políticas, são legítimas as afirmações de um conjunto heterogêneo

17 Uma discussão recente sobre as dificuldades da visão justificatória pode ser encontrada em Appiah (2008).

18 Essa noção, sugerida por Jeremy Waldron, lastreia-se, naturalmente, nas visões de Thomas Scanlon (1982, 2003) e John Rawls (1993, 1999), calcadas, respectivamente, na ideia de não objeção razoável e de razão pública.

${ }^{19}$ Kymlicka oferece um quadro sintético sobre o ponto (199a, p. 168-9, especialmente nota 6). 
de práticas morais, religiosas e culturais, conformando diversos estilos de vida e concepções do bem. Não parece haver, porém, espaço para pretensões a um direito moral de reprodução no tempo de determinadas doutrinas ou perspectivas éticas, em especial se essa sobrevivência depender de um acesso diferencial a recursos estatais - o que seria desarrazoado do ponto de vista dos demais cidadãos comprometidos com outras visões da boa vida ${ }^{20}$.

Da ótica prática, são apontadas dificuldades não só para mensurar, especialmente no médio e longo prazos, os efeitos líquidos da ação estatal sobre as práticas culturais e estilos de vida - isolados, naturalmente, de outras fontes societárias de influência ${ }^{21}-$, mas até para estipular um marco de referência, a partir do qual aqueles efeitos poderiam ser efetivamente avaliados (Waldron, 1993, p. 150) ${ }^{22}$. Essa argumentação é plausível, mas talvez mereça um adendo, pois os efeitos gerais mais diretos de uma lei, por exemplo, discerníveis na medida em que, digamos, consolida-se determinada interpretação administrativa e/ou judicial da norma, devem ser "internalizados" e passar a constituir objeto do próprio exercício de reconstrução ${ }^{23}$ do ato estatal destinado a testar sua razoabilidade. Uma visão ampla de neutralidade justificatória deveria, portanto, desde o início, "embutir", como parte da operacionalização do seu critério de adequação normativa, os efeitos de curto prazo da regra, desde que, naturalmente, identificáveis. Esse tipo de pretensão não parece, prima facie, estar aberto às críticas de cunho moral ou prático esboçadas.

${ }^{20}$ Essa última vedação moral não deve ser confundida com o exame a respeito da legitimidade de uma disposição ativa do Estado de sustentar a própria política de tolerância e de assegurar uma estrutura ampla de oportunidades para a conformação de padrões valiosos de conduta, individuais e coletivos.

${ }^{21}$ As fontes societárias de influência não parecem, em princípio, suscetíveis, em igual grau, à objeção interposta pela visão consequencial às eventuais implicações desiguais da ação do Estado; não apenas porque naquela hipótese restam ausentes os elementos coercitivos, mas também por força de se entenderem os efeitos não neutros, cristalizados no ambiente cultural, derivados de fontes societárias, como o acúmulo de um sem-número de escolhas individuais legítimas realizadas no decorrer de certo período de tempo. O tema, porém, exige tratamento detalhado, que vai bem além do que é possível fazer no presente trabalho.

${ }^{22}$ Crítico do emprego do termo "neutralidade", por suas implicações equívocas, entre as quais a própria sugestão consequencialista discutida, Rawls, contudo, nos termos da dicotomia utilizada no texto, estaria alinhado com a corrente justificatória. Ver, nesse sentido, os parágrafos 5 e 6 da palestra"Priority of right and ideas of the good"(1993, p. 190-200). Esse também é o entendimento de Kymlicka a respeito da perspectiva rawlsiana (1992a, p. 166-9). Sobre a impossibilidade da neutralidade consequencial, ver também Nagel (1991, p. 165-7).

${ }^{23}$ Reconstrução no sentido da reprodução crítica dos fundamentos da norma ou medida, exercício que permite emitir juízo sobre a sua natureza objetável ou não objetável. 


\section{Justificando a tolerância e a neutralidade: a inevitabilidade de hard-choices}

Inserida, na discussão, a noção de neutralidade estatal - correlata, como se assinalou, à própria concepção de tolerância como "respeito mútuo" volto-me, a partir daqui, para o tópico já anunciado da justificação mais substantiva dessas perspectivas. Escrevi que, em princípio, haveria diversos caminhos para justificar a noção de tolerância referida, legitimando-se, com isso, a própria ideia de neutralidade; sublinhei, ao mesmo tempo, a possibilidade de implicações institucionais diversas associadas a cada uma das alternativas disponíveis (Waldron, 1993, p. 151-3). Antes, porém, de apresentar esses modelos normativos de sustentação da tolerância, indico uma via argumentativa que, ao meu juízo, não pode justificar a tolerância e que, no limite, apresenta-se como um contrassenso. Trata-se de pretender justificar a tolerância liberal e a própria neutralidade correlata, demandada do Estado, por razões elas próprias neutras.

\section{Razões neutras para a neutralidade?}

A ambição de fundar a neutralidade e a tolerância em bases neutras ou segundo uma moralidade de ordem superior - como quer que se defina uma ou outra - aparece em alguns expoentes do pensamento liberal contemporâneo. Stephen Macedo (1995), em um texto de síntese da literatura sobre tolerância, flerta com esse objetivo, sugerindo que a incapacidade do liberalismo de dar conta dessa empreitada responderia por parcela de suas dificuldades, em especial junto às parcelas da população comprometidas com ideais religiosos ortodoxos (1995, p. 622-8) ${ }^{24}$. Macedo chega a indicar algumas tentativas de estabelecer essa fundação imparcial. Cita, como exemplo, o trabalho de Charles Larmore (Patterns of moral complexity), o qual localizaria em uma "norma universal de diálogo razoável” o suporte para uma justificação neutra da neutralidade. De pronto, porém, Macedo se apressa em questionar o potencial inclusivo dessa norma, a qual só geraria adesão entre os que prestam deferência à própria ideia de conversação razoável, revelando sua parcialidade - sua

\footnotetext{
${ }^{24}$ Numa veia análoga, no contexto de uma discussão acerca do multiculturalismo e de identidades coletivas, Galeotti sugere limitações do liberalismo contemporâneo para lidar com "culturais iliberais" (2008, 568-9). É no mínimo curioso que não ocorra nem à autora mencionada nem a Macedo que as "limitações" ou a "incapacidade" talvez resultem não de deficiências da abordagem liberal, mas, simplesmente, da imposição do que Rainer Forst chama de "cláusulas de rejeição", componente intrínseco, como se viu, a qualquer abordagem da temática da tolerância.
} 
qualidade, portanto, de norma moral não neutra - e o "fracasso" decorrente do pensamento liberal. Para Macedo, na verdade, o próprio Larmore parece reconhecer a impossibilidade de pleitear lealdade universal à norma sugerida (1995, p. 625). Diversamente, em uma perspectiva cética sobre as possibilidades de êxito desse tipo de empreendimento, Jeremy Waldron (1993, p. 152-3) aponta o trabalho de Bruce Ackerman - Social justice in the liberal State - como um exemplo de incoerência, uma vez que a pretensão de estender a neutralidade liberal sobre concepções éticas da boa vida para a própria justificação desse ponto de vista ignora, entre outras coisas, que a escolha entre diferentes concepções de tolerância e da neutralidade, com desiguais implicações sobre a ação estatal, depende da construção de argumentos normativos hábeis a explicar as razões, forçosamente não neutras, pelas quais valorizamos uma e outra.

Outro exemplo desse tipo de exercício vem de trabalhos de Thomas Nagel (1987, 1991). Valho-me, para comentá-los, de um ensaio de Susan Mendus sobre imparcialidade (2008, p. 423-35), no qual essa autora expõe o cerne dos dilemas que, segundo Nagel, confrontam o liberalismo político contemporâneo $^{25}$. Para Mendus (2008, p. 431), o critério de imparcialidade nos forneceria, em princípio, um teste adequado de legitimidade a ser aplicado sobre os princípios políticos que estruturam a nossa coexistência nas sociedades democráticas contemporâneas. No entanto, prossegue a autora, introduzindo os argumentos de Nagel, nem todos os concidadãos concordariam com o critério mencionado. Dado que o critério de imparcialidade visa a orientar o uso do poder coercitivo do Estado - vinculante para toda a cidadania -, a questão de sua justificação torna-se urgente. Como afirma o próprio Nagel, em trecho citado por Mendus (2008, p. 431), se, respaldados pela força, impusermos instituições congruentes com a imparcialidade (vetando, em consequência, outras possibilidades institucionais), o que nos autoriza a sustentar que "não estamos sendo tão parciais frente aos nossos próprios valores como alguém que impõe uma religião de Estado?” (Nagel, 1987, p. 222). Em outras palavras, o que pode justificar que consideremos o critério de imparcialidade como um ponto de vista moral superior frente a outras concepções do bem, tornando legítimo que o uso autorizado da força estatal possa ser invocado em seu suporte e ao mesmo tempo interditando esse uso quando em favor de outro conjunto de comprometimentos morais?

Para efeito desse trecho do trabalho, acredito poder considerar imparcialidade e neutralidade como termos intercambiáveis. 
É em resposta a essa questão que Nagel vai sustentar a necessidade de apelar a uma "ordem superior" de imparcialidade, de modo a oferecer, aos que sustentam outras perspectivas éticas, um argumento moral independente, capaz de sobrepujar razões concorrentes (Nagel, 1987, p. 223). Esse ponto de vista é sintetizado na seguinte passagem de Nagel (1987, p. 223), também destacada por Susan Mendus (2008, p. 432):

Se o liberalismo pretende ser defensável como uma teoria de ordem superior, e não apenas como mais uma doutrina sectária, é necessário mostrar que ele é resultado de uma interpretação da própria ideia de imparcialidade, e não de uma concepção particular do bem (...). Naturalmente, qualquer interpretação da imparcialidade será controversa do ponto de vista moral - não se cogita ascender a um ponto de vantagem acima de todas as disputas morais -, mas a controvérsia se dará em um plano diferente.

Acredito que a passagem transcrita condensa, na verdade, não os dilemas do liberalismo contemporâneo, mas, especificamente, o incômodo de todos aqueles que pretendem defender o princípio da neutralidade ou imparcialidade em termos eles próprios imparciais. No fundo, o problema resulta de se tentar perfazer uma espécie de quadratura do círculo, empreendimento que cedo ou tarde denuncia sua própria inconsistência. No caso em foco, pode-se dizer que, em primeiro lugar, o apelo a uma moralidade de "ordem superior" não interdita a própria contestação do valor da imparcialidade como critério-chave para guiar a organização da vida política. Adicionalmente, a ideia de que o liberalismo materializa ou, em um sentido mais forte, resulta de uma interpretação da própria noção de imparcialidade, não remove as possibilidades pluralísticas de compreensão do valor em questão, embutidas no próprio conceito de interpretação. Por outro lado, afirmar que a controvérsia se dará em "um plano diferente", ou em um "nível superior", não parece ser de grande auxílio, porquanto outras perspectivas não estão, em princípio, impedidas de se fazerem presentes - com exigências normativas distintas - nessa outra dimensão. A fratura entre posturas igualmente morais e conflitantes tão somente se replica para o patamar superior mencionado ${ }^{26}$. ${ }^{26}$ A própria passagem citada no texto, em seu último período, sugere que, no próprio momento em
que formula sua posição, Nagel é obrigado a reconhecer os seus limites. 


\section{Escolhas fundacionais ou hard-choices}

O ponto a ser salientado, por conseguinte, é que a tolerância e a neutralidade, de um ponto de vista liberal, dependem de escolhas fundacionais que estão longe de serem elas próprias neutras, no sentido de indiferentes ou compativeis com todo e qualquer arco imaginável de valores ou perspectivas morais. Em termos provocativos, pode-se dizer que o liberalismo tem inimigos reais e não pode (e nem deve) se furtar a essa realidade (Waldron, 1993, p. 57), porquanto sua defesa da tolerância impõe, a partir da própria ideia lógica do conceito, discutida anteriormente, a demarcação de fronteiras ou de uma cláusula de rejeição, para usar os termos de Rainer Forst (2007). Para desenvolver esse ponto, valho-me aqui, mais diretamente, de contribuições de Melissa Williams e Jeremy Waldron ${ }^{27}$. Nesse sentido, assinalam esses dois autores que uma argumentação em favor da tolerância e da neutralidade estatal não pode permanecer de pé independentemente dos valores com os quais estamos comprometidos e que, em última análise, lastreiam a nossa defesa daquelas perspectivas. Para Williams e Waldron, uma teoria "ultraliberal" da tolerância, que se pretenda ancorada em uma postura de neutralidade moral, conduz, necessariamente, a impasses insolúveis, uma vez que a própria tolerância se apoia em ideais em relação aos quais o liberalismo não pode postular neutralidade (2008, p. 8). Nos termos desses autores:

(...) sustentamos um princípio de tolerância (...) não porque valores não importem, mas porque valores como a paz, a diversidade, a autonomia e a integridade da consciência individual importam mais do que (digamos) os valores religiosos que poderíamos estar inclinados a apoiar mediante a ação do Estado e da lei $(2008 \text {, p. } 8)^{28}$.

27 Os textos de referências são Waldron (1993, p. 35-62, 143-67) eWaldron e Williams (2008, p. 1-28). Boa parte de sua argumentação de Waldron (1993, p. 56, nota 43) está ancorada nas premissas rawlsianas sobre uma concepção de justiça, em especial na forma como são apresentadas em A theory of justice (1971).

28 No mesmo espírito, escreve Waldron (1993, p. 156-7): "A neutralidade liberal não é e nem pode ser a doutrina de que a legislação deve ser neutra em relação a todos os valores morais. Ela certamente não é a doutrina de que a legislação deve ser isenta de valores [value-free], o quer que isto signifique. Essas ideias são incoerentes. A neutralidade é em si própria um valor, p. é uma posição normativa, uma doutrina acerca do que os legisladores e os responsáveis por decisões públicas devem fazer. É uma doutrina que sustenta que é errado permitir que certas considerações penetrem na arena política; é uma doutrina que apresenta a neutralidade na atividade política como justa e correta. (...). Os liberais consideram a neutralidade não apenas como um valor que deve condicionar o comportamento dos legisladores, mas também como um valor que precisa ser sustentado e aplicado (diante de pessoas que exerçam o poder mediante modos não neutros). Outra maneira de formular isso é simplesmente dizer, por exemplo, em seu próprio comportamento, mas também em relação ao comportamento das pessoas [sob sua jurisdição], não se espera que o legislador seja neutro a respeito da neutralidade." 
Para detalhar esse ponto, cabe reter dois pontos de referência que organizam a discussão: a pretensão liberal de estruturar princípios políticos de justiça capazes de aceitação geral e a realidade não contingente do pluralismo ético e religioso das sociedades contemporâneas. É nesse contexto que ganham sentido as temáticas, aqui examinadas, da tolerância e da neutralidade. A questão que desafia a teoria emerge, pois, de forma clara (Waldron, 1993, p. 56), pois de que forma é possível para pessoas comprometidas com ideais morais diversos e incomensuráveis, e muitas vezes também conflitantes e inconciliáveis, conviver pacificamente e convergir acerca de princípios hábeis a justificar, para além de um modus vivendi, suas principais instituições sociopolíticas?

A estratégia liberal para lidar com essa questão, consoante Waldron, tem consistido em "perseguir crenças e interesses comuns subjacentes [à diversidade de comprometimentos ético-morais], suscetíveis de apelo na justificação de arranjos institucionais" (1993, p. 56) ${ }^{29}$. Nesse sentido, o liberalismo buscaria identificar necessidades básicas derivadas de uma concepção abstrata de pessoa; bens e prerrogativas entendidos como meios para a consecução dos mais variados ideais; modos consensuais de argumento e raciocínio; convergências epistêmicas a respeito de como o mundo funciona etc. (1993, p. 56). Essencialmente, haveria, na reflexão liberal, a ambição de delinear a forma comum mediante a qual se materializaria, nas sociedades do nosso tempo, todo e qualquer comprometimento ético - essa forma consistiria em algo como a noção de levar à frente uma concepção de vida boa ou valiosa, empreendimento no qual, independentemente do conteúdo específico de suas crenças e comprometimentos, todos os indivíduos estariam envolvidos (Waldron, 1993, p. 56). Da mesma forma como, quando da emergência da tolerância religiosa, foi possível abstrair das profissões de fé concretas uma ideia abstrata do que significa honrar um vínculo transcendental, reconhecendo-se reciprocamente os diversos praticantes nessa condição e status, apesar de suas devoções específicas, seria possível, contemporaneamente, construir uma ideia similar ou análoga a partir da diversidade de estilos de vida e comprometimentos morais. O reconhecimento geral, ou pelo menos substancialmente amplo, de algo como um princípio de igual liberdade, ancorado ele próprio numa concepção igualitária de pessoa, ou de cidadão, e de suas faculdades

${ }_{29}$ Ou seja, a aposta é que arranjos institucionais que protejam e sustentem esses interesses subjacentes comuns tornem-se, pelo menos em tese, candidatos à legitimação ampla por parte da cidadania. 
morais essenciais, bem como em uma visão da sociedade como empreendimento cooperativo de base equitativa, nos termos propostos por John Rawls (1971, p. 220-1; 1993, p. 15-35; 1999, p. 395-9) ${ }^{30}$, seria um exemplo de uma das rotas hábeis a delimitar a pedra de toque de uma razoabilidade mínima de apelo amplo - ou seja, capaz de fundar os alicerces de uma justificação comum de arranjos sociais entre indivíduos perenemente comprometidos com concepções divergentes e conflitantes a respeito da boa vida.

No entanto, como já nos advertiram Nagel (1987) e Mendus (2008), nem todos os cidadãos concordam com as descrições ético-normativas da sociedade, dos indivíduos, de suas relações e interesses básicos propostas pela tradição liberal. Não é difícil identificar, nas sociedades multifacetadas do presente, exemplos de concepções antitéticas às que foram esboçadas anteriormente. Entre personagens tão díspares como o indivíduo de convicções religiosas ortodoxas - que vê na tarefa de salvar e purificar almas seu objetivo central - e o militante político extremista - que tem no centro de seus propósitos a edificação de um sistema social completamente alheio às estruturas do presente -, muitas vezes é possível encontrar a mesma rejeição da noção de "conversação razoável", de liberdade igual ou mesmo da possibilidade de um distanciamento reflexivo mínimo perante as próprias convicções. Adicionalmente, essas mesmas concepções ético-normativas do liberalismo podem aparecer, para alguns, como mera forma de reprodução de valores individualistas, céticos e "burgueses" (Nagel, 1991, p. 165; Macedo, 1995, p. 626-7), os quais deveriam ser substituídos por visões focadas em valores mais altruístas - ainda que os modelos de boa vida sustentados pelos porta-vozes do "altruísmo" precisem ser impostos aos recalcitrantes ${ }^{31}$.

Diante disso, nos termos de Waldron (1993, p. 57), o liberal confronta uma hard-choice. Um caminho requer que o liberalismo admita que seus modelos de sociedade, estado e indivíduo só têm ressonância moral e apelo para cidadãos que sustentam seus comprometimentos dentro de certo espírito "liberal" - capazes, por conseguinte, de distanciamento crítico mínimo diante de suas próprias convicções e inclinados a valorizar, de modo substantivo, ideias de igualdade moral e de justificação razoável recíproca, compatíveis

30 Refiro-me um pouco menos brevemente, adiante, às noções essenciais que fundamentam a concepção de justiça de Rawls. Menciono-a aqui como um exemplo de uma das mais importantes tentativas, no âmbito do liberalismo contemporâneo, de responder ao desafio discutido neste ponto do texto.

31 Sobre os efeitos de exacerbação dos conflitos decorrentes do altruísmo generalizado e irrestrito, ver Nagel (1991, p. 163-5). 
com a aceitação do pluralismo de formas de vida. A alternativa seria "buscar uma ordem social na qual não apenas [os indivíduos] com diferentes ideais, mas também aqueles sustentando diferentes visões a respeito [de modos legítimos] de impor seus ideais possam ser acomodados" (Waldron, 1993, p. 57). Nesse outro tipo de ordem social, a imaginação liberal estaria desafiada a pensar um tipo de associação capaz de satisfazer também o ortodoxo e o extremista não razoáveis e, em geral, todos aqueles que internalizam nas suas exigências de boa vida um requerimento de controle sobre vidas alheias e/ ou sobre o design das instituições sob as quais os outros devem viver. Um momento de reflexão tende a sugerir, contudo, que já não estaríamos, caso optássemos por esse segundo caminho, nos marcos do que tem sido entendido, ontem e hoje, como liberalismo. A primeira opção seria, assim, a única trilha disponível para os que persistem em sustentar os valores de igualdade, pluralismo e reciprocidade assinalados (Waldron, 1993, p. 57; Mendus, 2008, p. 435). Se é assim, não há como deixar de admitir que o liberalismo - para continuar sendo uma doutrina normativa com um significado específico não pode ser justificável a toda e qualquer perspectiva moral. Encontramos, assim, os limites da tolerância e da neutralidade liberal, sem os quais a própria perspectiva em exame não pode conservar sua integridade ${ }^{32}$.

32 A recusa a admitir a necessidade de realizar hard-choices ou a tentativa de alçar-se a uma "moralidade superior" mais inclusiva, com resultados, no entanto, pouco atrativos do ponto de vista político-normativo, talvez possam ser apontadas em aspectos da obra de John Rawls posteriores a sua $A$ theory of justice (TJ). Nesse sentido, a decisão rawlsiana de dividir em dois estágios a exposição de sua concepção de justiça - já presente na TJ, mas reiterada e acentuada a partir de trabalhos emergentes a partir da segunda metade da década de 1980 (por exemplo, Rawls, 1993 e 1999, p. 473-96), enfocando, no último estágio, a noção de estabilidade e centrando-se na ideia de overlapping consensus como estratégia para tornar congruente o pluralismo moral societário e a adesão substantiva a instituições democráticas - é criticada por Brian Barry (1995), para quem tal procedimento arrisca comprometer o núcleo normativo essencial de "justiça como equidade". Em especial, para Barry, a ideia de Rawls de que os princípios de justiça precisam ser afirmados a partir do interior de cada doutrina abrangente, isto é, nos próprios termos dessas perspectivas morais abrangentes, aproxima-se do que ele denomina de "anarquismo filosófico", o qual torna soberano, como instância de legitimação política, os julgamentos privados (1995, p. 914-5). Ao meu juízo, o texto de Barry ajuda a iluminar uma possível inversão, de importantes consequências, no modo como uma concepção de justiça é pensada por Rawls para sociedades pluralistas nos seus últimos escritos. De forma extremamente resumida, trata-se, no limite, do enfraquecimento da noção da prioridade do justo sobre o bem, crucial para a própria estruturação original de "justiça como equidade". De maneira geral, essa prioridade permite delimitar o leque de concepções do bem permissíveis, ou seja, compatíveis com o conteúdo dos princípios de justiça. Os limites da tolerância ou as fronteiras de razoabilidade, no interior das quais podem circular diferentes perspectivas morais presentes em uma sociedade bem-ordenada, são estabelecidos, assim, pela própria concepção de justiça. Na medida, porém, em que os princípios passam a necessitar de legitimação a partir de "dentro" das doutrinas abrangentes, não é claro quem fornece razoabilidade a 
Naturalmente, os contornos exatos desses limites ou o âmbito do território normativo específico adequado a ser diferenciado de outros, situados externamente aos marcos traçados pela cláusula de rejeição liberal, são objeto de negociação contínua e de permanente debate (Macedo, 1995, p. 627) prático e teórico. As próprias estratégias e os argumentos morais que fundam a tolerância e a neutralidade, como já assinalado, estão sujeitos à controvérsia no interior do próprio liberalismo contemporâneo, demarcando distintas perspectivas a respeito das vias mais adequadas de justificação de seus principais postulados, com implicações para as demarcações de fronteiras referidas e, em geral, para a ação do Estado. A discussão de dois modelos de justificação e uma proposta de síntese, inspirada em Rawls, é o próximo assunto do texto.

\section{Autonomia, justificação razoável e uma possível síntese rawlsiana}

A tolerância diante de perspectivas religiosas, morais e éticas distintas muitas vezes conflitantes entre si - não pode se lastrear em uma perspectiva moralmente neutra, conforme desenvolvido, mas envolve a atribuição de uma importância especial a valores diversos como a paz; o desenvolvimento da individualidade; a diversidade de situações (em termos de um amplo e variado leque de estilos de vida e pontos de vista éticos sobre a existência

quem. A questão só cresce em relevância quando atentamos para a passagem, no Political liberalism (1993, p. 65-6), em que Rawls se pergunta o que caberia fazer se os princípios de justiça decorrentes do primeiro estágio fracassassem na obtenção de apoio da parte das doutrinas "razoáveis" (1993, p. 65). Após afirmar que a sua concepção estaria, nessas circunstâncias, em dificuldades, Rawls sugere algumas linhas práticas de ação, entre as quais considerar se "mudanças aceitáveis nos princípios de justiça [poderiam] produzir estabilidade". Nessa última sugestão de Rawls, teríamos, então, a chancela expressa a uma inversão das fontes primárias de razoabilidade, pois, em vez da concepção de justiça colocar, ela própria, de forma antecedente, limites externos de razoabilidade às doutrinas do bem, seriam estas últimas que, das suas próprias perspectivas, legitimariam (como condição da estabilidade) a concepção, aberta esta, consequentemente, a mudanças e ajustes no intuito de alcançar aquele objetivo. Como, adicionalmente, não existiriam, nos termos de Barry, "vantagens competitivas" de sobrevivência associadas a doutrinas desde logo harmônicas com os princípios de justiça rawlsianos (1995, p. 911-4), ficaríamos, ao final das contas, desarmados, em termos normativos, para lidar com o pluralismo contemporâneo. Em sentido contrário ao conteúdo dessa nota, uma visão da razoabilidade das doutrinas compreensivas como função de sua subordinação a limites postos previamente pela concepção de justiça está presente, por exemplo, nas palestras ("The powers of citizens and their representation") e 5 do Political liberalism ("Priority of right and ideas of the good") e no trecho assinalado do ensaio "The domain of the political and overlapping consensus" (1999, p. 486-8, mais expressamente na nota 30). Esse tipo de visão seria, no entanto, à luz da interpretação de Barry (1995, p. 890-6), parte apenas do primeiro "estágio" da apresentação da concepção de justiça, posta em risco pela busca da "estabilidade" no último estágio. 
humana); as liberdades de consciência e de pensamento e da busca, por caminhos próprios, da felicidade; a coexistência pacífica em bases mutuamente aceitáveis etc.

De forma simplificada, podemos afirmar que, mais recentemente, dois tipos diferentes de justificação buscam articular, em um esquema coerente, o amálgama referido de razões (e muitos outros motivos, omitidos aqui) de modo a fornecer uma âncora ético-normativa mais sólida à tolerância (Forst, 2007, p. 10-1). Ambos os tipos também se concebem na medida em que emprestam esteio a uma postura neutra da autoridade política frente aos comprometimentos variados de seus cidadãos, em sinal de respeito a sua igualdade moral. O primeiro esquema de justificação se centra na noção de autonomia; e o segundo, na ideia de justificação razoável. Passo a apresentar versões sumárias de cada um, lembrando que substantivas variações e refinamentos estão presentes na literatura, ademais de outros tipos de justificação, sendo o objetivo do presente trabalho somente uma visita ao núcleo básico dos respectivos argumentos dos dois esquemas mencionados. Após apresentá-los, detenho-me em algumas ideias de Rawls sobre o assunto, as quais, ao meu juízo, podem sugerir vias de síntese e de desenvolvimento a partir dos dois posicionamentos iniciais.

\section{O modelo da autonomia}

O modelo de justificação normativa centrado na autonomia destaca que o respeito pelos indivíduos envolve (e requer, do ponto de vista moral) entendê-los como seres autônomos, do ponto de vista ético e pessoal, portadores de capacidades que os habilitam a escolher e levar à frente seus próprios comprometimentos centrais, retendo também o poder de revisá-los e alterá-los, à luz de novos juízos axiológicos emergentes no curso de suas existências - no caminho de Damasco, Paulo de Tarso transformou-se em Paulo, o apóstolo, no célebre exemplo de Rawls (1999, p. 405). As políticas estatais e a própria arquitetura institucional de uma sociedade justa devem ter, em consequência, como objetivo a proteção e a garantia das liberdades e prerrogativas que lastreiam o exercício da autonomia, sendo a neutralidade estatal requerida diante da multiplicidade de formas concretas de vida hábeis a emergir nesse tipo de ambiente societário. Trata-se, em princípio, de favorecer arranjos institucionais preocupados com as formas pelas quais os indivíduos criam suas próprias vidas e menos com o conteúdo concreto 
dessas escolhas, desde que respeitados os limites de igual liberdade e a integridade dos concidadãos.

São evidentes os ecos, nesse tipo de concepção, dos escritos de John Stuart Mill, em particular aqueles presentes em On liberty (1988). Nessa obra, Mill vai realizar a defesa “(...) da liberdade dos homens para agir segundo as suas opiniões - para levá-las à prática, na sua vida, sem obstáculo, físico ou moral, da parte dos seus semelhantes, enquanto o façam por sua própria conta e risco" (1988,zz p. 97). De modo mais amplo, tanto a diversidade de opiniões como a de estilos de vida são vistas - dentro de certos parâmetros, consubstanciados no chamado harm principle $e^{33}$ - um serviço prestado à sociedade como um todo, interessada na verdade e no progresso, metas atingíveis somente em um ambiente de liberdade e experimentação ${ }^{34}$. Confere-se, portanto, status moral especial aos atributos da espontaneidade, individualidade e originalidade, sendo seus pressupostos centrais a liberdade humana e a própria variedade de situações (Mill, 1988, p. 98-9). Sem prejuízo da valorização do manancial de experiências decantado historicamente pela tradição e pelos costumes de uma sociedade, parece inerente a uma visão do homem, nos termos sustentados por Mill, que ele, quando no pleno gozo da "maturidade de suas faculdades", se constitua no árbitro final apto a discriminar que parcela da "experiência registrada se aplica, com propriedade, às suas circunstâncias e caráter” (1988, p. 99-100).

No entanto, para muitos estudiosos contemporâneos (Macedo, 1995, p. 623-6; Forst, 2007, p. 10), não obstante seus méritos e qualidades, a concepção de Mill ou visões derivadas - fundadas, em última análise, na ideia de autonomia - não se apresentam adequadas para lastrear moralmente a

${ }_{33}$ Nos termos de Mill (1988, p. 53): "Consiste esse princípio em que a única finalidade justificativa da interferência dos homens, individual e coletivamente, na liberdade de ação de outrem, é a autoproteção. O único propósito com o qual se legitima o exercício do poder sobre algum membro de uma comunidade civilizada contra a sua vontade é impedir zdano a outrem. O próprio bem do indivíduo, seja material seja moral, não constitui justificação suficiente. O indivíduo não pode legitimamente ser compelido a fazer ou deixar de fazer alguma coisa, porque tal seja melhor para ele, porque tal o faça mais feliz, porque na opinião dos outros tal seja sábio ou reto. Essas são boas razões para admoestá-lo, para com ele discutir, para persuadi-lo, para aconselhá-lo, mas não para coagi-lo ou para Ihe infligir um mal caso aja de outra forma. Para justificar a coação ou a penalidade, faz-se mister que a conduta de que se quer desviá-lo tenha em mira causar dano a outrem."

34 "Assim como é útil, enquanto a humanidade seja imperfeita, que haja diferentes opiniões, assim também o é que haja diferentes experiências de maneiras de vida, que se deem largas livremente, salvo a injúria a outrem, às variedades de caráter, e que o mérito dos diversos modos de vida seja praticamente provado, quando alguém se julgue em condições de experimentá-lo" (Mill, 1988, p. 98). 
tolerância e a neutralidade nas nossas sociedades democráticas e pluralistas. A razão fundamental dessa rejeição repousa em que a pluralidade mesma de concepções da boa vida - tão exaltada por Mill como materialização concreta da liberdade de experimentação humana -, em um contexto de instituições livres, acolhe visões de mundo portadoras de reservas e de restrições frente ao próprio valor da autonomia, quando entendida como concepção "cheia" ou doutrina abrangente do bem viver. Imbuídas de respeito pela tradição ou atreladas a visões religiosas ou comunitárias, refratárias, por exemplo, ao individualismo não conformista, muitas perspectivas éticas, prima facie congruentes com o pluralismo liberal, não comungam elas próprias com os valores abrangentes de um liberalismo ao estilo de Mill ou Kant, os quais, nos termos de Rawls (1993, p. xliv, xlv, 37, 77-8; 1999, p. 408-9), não são apenas uma concepção de justiça política, mas doutrinas compreensivas - no sentido de incluírem uma visão axiológica de todas ou quase todas as dimensões da existência humana, nesse sentido rivalizando com outras perspectivas morais.

Em consequência, fundar normativamente a tolerância e a neutralidade na ideia de autonomia provocaria efeitos indesejáveis de sectarização e de estreitamento, aumentando, por exemplo, as tensões entre as instituições liberais e determinadas versões do pensamento religioso (Macedo, 1995, p. 624); sobretudo, implicaria, no final das contas, em riscos de paternalismo e de enfraquecimento da base potencial de adesão às instituições liberais (Forst, 2007, p. 10).

Em sentido contrário, procurando resgatar visões derivadas da contribuição de Stuart Mill e tributárias da noção de autonomia, autores como Kymlicka (1992b) se empenham em argumentar que as noções de direitos, garantias e liberdades - centrais à tradição liberal - dependem da defesa, em algum grau, do valor da autonomia ${ }^{35}$. O desafio, por conseguinte, passa a ser a construção de razões centradas na autonomia, as quais não se mostrem vulneráveis às críticas alinhavadas aqui. Para Kymlicka (1992b, p. 40-3), isso é possível se precisarmos com exatidão a noção em foco, apartando-a de conotações mais abrangentes ${ }^{36}$. Mediante essa operação, segundo o autor, é possível dizer que o núcleo de um argumento favorável

35 The morality of freedom, de Joseph Raz (1986, Oxford, Clarendon Press), é o texto-chave na literatura recente a defender um liberalismo fundado na autonomia.

36 Depurando-as, portanto, de aspectos ligados às perspectivas morais totalizantes de Kant ou do próprio Stuart Mill (Kymlicka, 1992b, p. 41 e nota 9). 
à autonomia repousa na "visão de que nós temos um interesse básico em sermos capazes de apreciar racionalmente e revisar" os fins e propósitos últimos que sustentamos, de modo a checarmos, a qualquer tempo, o valor de persegui-los (1992b, p. 41). Em outros termos, o "direito de saída", frente a laços associacionais, bem como a revisibilidade dos nossos ideais mais caros são, consoante essa ótica, componentes inelimináveis de qualquer justificação normativa das instituições liberais e, talvez, sejam mais bem capturados pela noção de autonomia, desde que requalificada e subtraída de conotações mais sectárias ${ }^{37}$.

\section{O modelo da justificação razoável}

O segundo modelo que busca fundar, de modo coerente e sistemático, a tolerância e a neutralidade se apoia na noção de justificação razoável. Nesse sentido, sem recair nas armadilhas do que chamei antes de quadratura do círculo, postulando uma quimérica fundação moralmente neutra dos valores em discussão, esse segundo empreendimento normativo visa, contudo, a evitar seu comprometimento com concepções particulares do viver bem - o que prejudicaria suas pretensões não discriminatórias e de imparcialidade frente à cidadania. Em função disso, a ideia é ancorar as instituições da tolerância em um princípio de justificação ou de não objeção razoável (Scanlon, 1982), o qual sustenta que normas coercitivas vinculantes para uma pluralidade moralmente heterogênea de pessoas "devem poder ser objeto de justificação lastreada em razões reciprocamente aceitáveis para todos os afetados" (Forst, 2007, p. 10-1); em uma formulação de matriz scanloniana, o princípio requer - acolhido o pressuposto de uma motivação moral geral de justificação recíproca, presente em cidadãos que se compreendem como livres

"O modelo liberal (...) proporciona às pessoas acesso à informação sobre outros modos de vida (através do proselitismo) e, na verdade, requer que as pessoas aprendam a respeito dessas opções (mediante a educação compulsória), abrindo espaço para que (...) [elas] revisem radicalmente seus fins (a apostasia não é crime). Esses aspectos de uma sociedade liberal só fazem sentido, eu penso, no pressuposto de que nós temos um interesse não apenas em perseguir nossas concepções correntes do bem, mas também em sermos capazes de examinar e potencialmente revisar essas concepções. O modelo liberal assume que a revisão dos fins é tanto possível como muitas vezes desejável. Ele supõe que os propósitos correntes das pessoas não são sempre dignos de sua lealdade continuada e que a exposição a outros modos de vida auxilia as pessoas na realização de julgamentos informados acerca do que verdadeiramente tem valor" (Kymlicka, 1992b, p. 43). Em termos mais diretos, uma visão "depurada" da autonomia sustentaria o reconhecimento público do "direito de saída" - em nome do direito à revisibilidade das lealdades - mas não emprestaria valor especial aos projetos de vida calcados na autonomia no sentido milliano. 
e iguais - que as normas ancoradas no poder estatal satisfaçam o critério da não objeção razoável. É a partir do ideal mesmo de igualdade moral de cada cidadão que se deriva essa demanda de justificação geral para instituições e ações políticas estatais fundamentais, sob a égide das quais deverão todos os indivíduos levar suas vidas (Waldron, 1993, p. 44-5).

Um argumento completo a favor da tolerância, entretanto, deve embutir, segundo Rainer Forst, um "componente epistemológico", o qual conduz ao entendimento de que "razões de ordem religiosa ou ética, se reciprocamente contestadas, não podem ser suficientes para justificar o exercício da força, uma vez que sua validade depende de uma fé particular [ou de um comprometimento ético específico] que pode ser razoavelmente rejeitada por outros que não a compartilham" $(2007, \text { p. } 11)^{38}$, visto que, sobre tais matérias, seria indevido postular julgamentos de verdade objetiva. Disso resulta que essa perspectiva da tolerância requer, normativamente, a compreensão de que "razões de objeção ética, ainda que profundamente arraigadas, não podem ser válidas enquanto razões gerais de rejeição, na medida em que (...) [ambas as ordens de razões possam ser] (...) [objeto de rejeição recíproca] (...) por conta de pertencerem a uma concepção do bem (...) não necessariamente compartilhada” pelos demais cidadãos (2007, p. 11). Os limites da tolerância acompanhariam, em seus contornos, as fronteiras delimitadas a partir da exigência de respeito ao próprio princípio de justificação assinalado, tornando o seu reconhecimento o emblema da razoabilidade.

Em minha opinião, em que pese o forte apelo desse segundo modelo, sua atratividade ética e política depende de desenvolvimentos normativos adicionais, aos quais é reservada a tarefa de substantivar descrições morais mais plenas da noção de sociedade, indivíduo e de suas relações. Podemos encontrar esse trabalho adicional em alguns aspectos da obra de John Rawls, aos quais dedicarei atenção nos próximos parágrafos.

\section{Rawls, a justificação razoável e uma proposta de síntese}

Pensar a tolerância e a neutralidade à luz da reflexão rawlsiana ${ }^{39}$, certamente redunda em uma aproximação maior com o segundo modelo nor-

\footnotetext{
38 As raízes históricas desse componente, de importância central para a literatura contemporânea sobre tolerância (vide a noção rawlsiana já referida de burdens of judgment), remontariam, de acordo com Forst (2007, p. 7-8, 11), ao pensador francês Pierre Bayle (1647-1706).

39 Ver nota 23.
} 
mativo apresentado, centrado na noção de justificação razoável ${ }^{40}$. O modo peculiar, porém, como Rawls realiza essa empreitada parece-me não só esclarecer mais nitidamente os fundamentos morais dessa noção, tornando-os mais sólidos e persuasivos, mas também incorporar os aspectos éticos essenciais suscitados por uma visão "depurada" da autonomia, nos termos propostos por Will Kymlicka e assinalados anteriormente. Nesse sentido, a visão que pode ser extraída do liberalismo rawlsiano acerca dos temas aqui em exame aponta, ainda que preliminarmente, para uma síntese inclusiva dos dois modelos normativos esboçados ${ }^{41}$.

No essencial, creio que o núcleo fundacional em Rawls, para pensar a justificação da tolerância e da neutralidade, é encontrado em dois conjuntos de ideias presentes na sua obra, os quais contêm uma parte importante de suas descrições ético-normativas sobre a sociedade, as pessoas, suas relações e suas crenças e comprometimentos morais. Essas ideias, como se verá, produzem a necessidade de uma concepção política liberal de justiça ao mesmo tempo que condicionam o seu conteúdo.

Em termos sumários, refiro-me aos dois seguintes grupos de ideias: o conjunto de ideias articulado em torno da noção da sociedade bem-ordenada como um sistema de cooperação social equitativa entre pessoas livres e iguais (1993, p. 15-22, 29-34; 1999, p. 393-9, 481); e os chamados "cinco fatos gerais" (1993, p. 35-40, 54-66; 1999, p. 474-9), os quais sintetizam os principais pressupostos presentes na concepção rawlsiana de justiça a respeito do mundo político e social $(1999 \text {, p. } 474)^{42}$.

O primeiro grupo de ideias, que materializaria uma estilização e o desenvolvimento de noções implícitas na cultura pública de uma sociedade democrática, está no centro da concepção de justiça rawlsiana (1999, p.

${ }^{40}$ Entre outros aspectos, a reconhecida proximidade da reflexão rawlsiana com aspectos da perspectiva contratualista de Thomas Scanlon, bem como a já referida noção de burdens of judgment, parecem justificar essa assertiva. Sobre o ponto, ver, em particular, os três primeiros parágrafos da palestra"The powers of citizens and their representation" em Political liberalism (1993, p. 48-66).

${ }^{41}$ Naturalmente, não pretendo afirmar que essas são as perspectivas que Rawls sustentou necessariamente sobre a matéria. Uso a expressão "rawlsiano" mais no sentido de afinidade do que de uma interpretação que se pretenderia"fiel"ao que esse autor desejou defender. Ademais, menciono no texto apenas alguns conceitos e concepções presentes na reflexão do autor referido, sem ter o propósito, obviamente, de realizar uma apresentação mais geral de suas visões.

42 "Justiça como equidade começa com a ideia intuitiva fundamental de uma sociedade bem-ordenada como um sistema equitativo de cooperação entre cidadãos considerados livres e iguais. Essa ideia junto com os cinco fatos gerais mostra a necessidade de uma concepção política de justiça" (Rawls, 1999, p. 481). 
395-6). Consoante Rawls, do ponto de vista político, “(...) e no contexto das discussões públicas de questões políticas” (1999, p. 396), os cidadãos enxergam a sociedade como um empreendimento cooperativo, guiado por regras e procedimento públicos reconhecidos e vistos como adequados. Sobretudo, além de reservar espaço para a persecução de objetivos parciais (de indivíduos, famílias, associações etc.), os quais remetem às concepções do bem ou aos valores de cada participante do esquema cooperativo, a ideia de cooperação envolve, no seu núcleo central, a noção de termos equitativos de cooperação resultantes de um acordo livre entre os cidadãos. Caracterizar esses termos é a função reservada, justamente, à concepção política de justiça ${ }^{43}$ (1999, p. 396). Na reflexão rawlsiana, recorde-se, o objeto primário da justiça vem a ser a estrutura básica da sociedade (suas principais instituições políticas, econômicas e sociais). A concepção de justiça, em consequência, alcança seus objetivos - fixar os termos equitativos da cooperação social -, formulando princípios "que especificam os direitos e deveres fundamentais no interior das principais instituições da sociedade" (1999, p. 396) e que regulam condições gerais de fundo hábeis a garantir regras equitativas de justiça distributiva. Condicionando a possibilidade de construção desses termos de cooperação, está um pressuposto de motivação moral scanloniano, o qual expressa uma disposição geral de edificar, em termos livres e voluntários, um padrão público de justiça, haja vista o desejo recíproco de justificação razoável (Rawls, 1993, p. 48-54 e notas 1 e 2; 1999, p. 395).

Por sua vez, a concepção política de pessoa livre e igual - que Rawls cuida de diferenciar desde o início de uma teoria da natureza humana, de cunho religioso, filosófico ou sociológico, em respeito à própria pluralidade de convicções sobre a matéria em uma sociedade democrática - repousa na noção de que os cidadãos são considerados como detentores, em grau adequado, de duas faculdades morais, e dos poderes da razão e do juízo que os acompanham, os quais os habilitam à plena participação em um esquema de cooperação equitativo (Rawls, 1993, p. 15-22, 29-35; 1999, p. 397 , nota 15).

\footnotetext{
${ }^{43}$ Nas palavras de Rawls, "(...) esses são termos que cada participante pode razoavelmente aceitar, contanto que os demais os aceitem igualmente. Termos equitativos de cooperação especificam uma ideia de reciprocidade ou mutualidade, p. todos os que se engajam na cooperação e cumprem sua parte, do modo requerido pelas regras e procedimentos, se beneficiam de um modo apropriado à luz de um adequado marco de comparação. Uma concepção política de justiça caracteriza os termos equitativos de cooperação social" (1999, p. 396).
} 
Essas faculdades morais consistem na capacidade de desenvolver um senso de justiça e uma concepção do bem (Rawls, 1993, p. 18-9; 1999, p. 397-8 $)^{44}$. Cidadãos dotados de um senso de justiça podem se comportar de acordo com os requerimentos do padrão público de justiça, entendendo seus conteúdos e sendo capazes de aplicá-los uma vez presentes circunstâncias adequadas. A noção de um comportamento razoável, ancorado no tipo de motivação moral aqui aludido, integra, portanto, a própria noção política de pessoa e introduz, adicionalmente, a noção de responsabilidade de cada um pelos objetivos e pretensões apresentados às instituições, os quais devem se adequar aos limites estabelecidos pela justiça (Rawls, 1999, p. 407). Por outro lado, como possuidores de uma concepção do bem, os cidadãos são vistos como vinculados a determinados fins e propósitos considerados dignos de sua lealdade, os quais orientam, em termos amplos, suas escolhas, preferências e comprometimentos mais cotidianos.

Sobretudo, porém, no que interessa mais de perto para este texto, os cidadãos, na perspectiva rawlsiana, são entendidos como fundamentalmente interessados em resguardar prerrogativas de "revisibilidade", no sentido utilizado por Kymlicka, frente as suas concepções correntes do bem, uma vez quze estas não podem ser compreendidas como fixadas de uma vez por todas, mas são formadas e se “(...) desenvolvem [na medida em que as pessoas] amadurecem, podendo se alterar mais ou menos radicalmente durante o curso da vida" (Rawls, 1993, p. 20). Nesse sentido, já aqui se constata que a noção "depurada" de autonomia, reivindicada por Kymlicka, está presente no esquema rawlsiano ${ }^{45}$. Essa conclusão se reforça quando examinamos o desdobramento que Rawls realiza da noção de concepção política de pessoa, distinguindo suas diferentes dimensões de liberdade, em uma sociedade democrática justa, no interior das quais ganha centralidade a distinção entre identidade "pública" e identidade "não pública"46 - com alterações na segunda

44 "Um senso de justiça é a capacidade de compreender, aplicar e agir a partir de uma concepção pública de justiça que caracteriza os termos equitativos da cooperação social. Dada a natureza da concepção política, voltada à especificação de uma base pública de justificação, um senso de justiça expressa também uma disposição, quando não o desejo, de agir em relação aos outros em termos que eles possam também publicamente afirmar. A capacidade para [possuir] uma concepção do bem é a capacidade de formar, revisar e racionalmente perseguir uma concepção da própria vantagem racional ou do bem" (Rawls, 1993, p. 19).

45 Sobre o ponto, ver também Rawls, 1999, p. 398.

${ }^{46}$ Respectivamente, a nossa identidade (pública) perante as instituições políticas, substantivada na cidadania, lastreada nas faculdades morais e de juízo e julgamento associados, nos termos expostos no 
sendo, em geral, de implicações nulas para a primeira ${ }^{47}$. Em uma sociedade democrática, isso é consequência do fato de que o exercício legítimo de direitos e de pretensões não depende de filiações religiosas, posição de classe ou de comprometimentos ético-morais específicos (Rawls, 1993, p. 29-35; 1999 , p. 404-6 $)^{48}$. Para voltar ao exemplo clássico retomado por Will Kymlicka (1992b, p. 43), a apostasia não é crime em uma sociedade democrática e pluralista guiada por princípios rawlsianos de justiça.

O segundo grupo de ideias a que pretendo fazer referência consiste nos chamados cinco fatos gerais, os quais condensam as suposições principais constantes da concepção rawlsiana de justiça a respeito do mundo político e social (1999, p. 474-9), reconhecendo, também, determinadas realidades da "sociologia política" e da "psicologia humana", presentes na nossa vida contemporânea (1999, p. 474).

Em uma exposição rápida, os fatos podem ser sumariados da seguinte forma. O primeiro deles vem a ser o que Rawls denomina de "fato do pluralismo" (1999, p. 474), o qual aponta a natureza permanente da diversidade de doutrinas abrangentes éticas (de cunho religioso, filosófico ou moral) nas sociedades democráticas contemporâneas. A coexistência e a persistência no tempo de perspectivas distintas e mesmo inconciliáveis, em termos de comprometimentos éticos últimos, emergem como uma implicação natural do exercício das liberdades e direitos fundamentais assegurados pelas instituições liberais. O segundo fato, intimamente relacionado, conduz à constatação de que só a utilização autocrática do poder estatal pode lograr a supressão da diversidade moral, produzindo uma convergência geral em termos de visões de mundo (1999, p. 474-5). A preservação das liberdades fundamentais é, assim, antitética a essa unidade ${ }^{49}$. O terceiro fato salienta

texto, e a nossa identidade (privada), refletindo nossas outras lealdades e compromissos morais mais abrangentes, englobando nossas visões gerais de mundo, os vínculos de família, amizade e parentesco, aqueles decorrentes do pertencimento a uma religião, cultura, partido político, sindicato etc.

47 Daí que a extraordinária transformação porque passa a vida de Paulo de Tarso, no caminho de Damasco, citada antes, não tenha quaisquer efeitos em sua condição de cidadão livre e igual, fosse aquele personagem membro de uma comunidade liberal justa nos termos propostos por Rawls.

48 "(...) [na condição de pessoas livres], os cidadãos sustentam o direito de ver suas pessoas como independentes e não identificadas com qualquer concepção particular do bem, ou esquema finalístico. Dados seus poderes morais para formar, revisar e racionalmente perseguir uma concepção do bem, suas identidades públicas como pessoas livres não são afetadas por mudanças ao longo do tempo em suas concepções do bem" (Rawls, 1999, p. 404-5).

49 Nesse sentido, anota Rawls (1999, p. 475), não é possível ver a Inquisição como um "acidente" no contexto da Idade Média ocidental. 
que a existência segura e continuada de um regime democrático depende do apoio "voluntário" e "livre" da "maioria substancial de seus cidadãos politicamente ativos" (Rawls, 1999, p. 475). Como a cidadania é heterogênea, do ponto de vista de seus comprometimentos éticos e morais mais amplos, os padrões públicos de justiça não podem discriminar ou se confundir com concepções particulares do viver bem, sob pena de enfraquecer suas pretensões de angariar sólida legitimidade societária. O quarto fato localiza na cultura política pública de uma sociedade democrática o substrato de "certas ideias intuitivas fundamentais a partir das quais é possível desenvolver uma concepção política de justiça” para um regime democrático (1999, p. 475).

Por sua vez, o quinto dos fatos elencados por Rawls - os "limites da capacidade de juízo ou julgamento" (1993, p. 54-8) 50 $^{50}$ emerge da explicação que Rawls considera necessária para esclarecer os dois primeiros fatos. Trata-se de esboçar as razões pelas quais o livre exercício das faculdades morais e das capacidades de juízo por parte de cidadãos razoáveis, no âmbito de uma sociedade democrática, não conduz, no longo prazo, a perspectivas e visões uniformes, mas sim à diversidade caracterizada pelo "fato do pluralismo". A explicação das fontes de desacordo, enfatiza Rawls, deve ser compatível com a razoabilidade dos cidadãos que divergem entre si - ou seja, grosso modo, com as motivações morais scanlonianas antes referidas. Daí que causas como o preconceito, o "autointeresse", os erros lógicos ou a simples "miopia" irracional sejam descartadas, sendo necessário procurar por outras fontes para a discórdia, congruentes, consoante mencionado, com a condição de razoabilidade atribuída aos membros de uma sociedade justa (Rawls, 1993, p. 54-6; 1999, p. 475-6).

Para Rawls (1993, p. 56-7), entre outros motivos, as fontes das limitações da capacidade de juízo ou julgamento residem nas seguintes realidades, vistas como incontornáveis, as quais irei, a seguir, mencionar: o caráter complexo das evidências empíricas e científicas envolvidas torna difícil, muitas vezes, a avaliação convergente de um problema ou de um argumento (1); ainda que haja concórdia no que tange à natureza do tipo relevante de conside-

50 No seu ensaio "The domain of the political and overlapping consensus"(1999, p. 473-96), Rawls utiliza o termo burdens of reason (1999, p. 475), em contraste com burdens of judgment, noção que aparece em Political liberalism. Como este último volume é de 1993, posterior à publicação original do ensaio mencionado, que data de 1988, optei no texto por "limites da capacidade de juízo". Não percebi mudanças no conteúdo da ideia, mas o exame de eventuais alterações na concepção foge aos meus objetivos neste trabalho. 
rações, a atribuição diferente de pesos e da importância destas dificulta conclusões similares (2); conceitos morais e políticos, mas não apenas esses, são sempre, em alguma medida, vagos e indeterminados; essa característica requer o recurso a julgamentos e interpretações (e a "julgamentos acerca de interpretações"), o que sempre abre espaço para resultados avaliativos dessemelhantes (3); os modos de apreciar evidências e de ponderar valores morais e políticos são, em algum grau, dependentes da experiência que os indivíduos acumularam no curso de suas vidas. Essa experiência é, forçosamente, extraordinariamente heterogênea nas sociedades modernas, caracterizadas por complexa divisão do trabalho, por variados grupos sociais, por diversidade étnica etc., o que termina por concorrer para a divergência de julgamentos e juízos (4); com frequência é difícil avaliar, em termos líquidos, a força de argumentos normativos concorrentes envolvidos em uma dada questão (5); por último, como acentuava Isaiah Berlin, é limitado o espaço social de qualquer sistema de instituições, conduzindo a uma necessidade de escolhas e/ou restrições em termos de um conjunto de valores morais e políticos; essas opções envolvem decisões dilemáticas, já que é impossível realizar simultaneamente tudo que possamos considerar valioso $(6)^{51}$.

$\mathrm{O}$ ponto central de interesse aqui consiste em sublinhar a suposição rawlsiana de que os cidadãos, em uma sociedade democrática justa, são plenamente cientes dos limites assinalados, levando-os em consideração e aceitando suas consequências quando envolvidos na deliberação e discussão de questões públicas - em especial, quando atinentes a direitos e liberdades fundamentais e a problemas de justiça distributiva (Rawls, 1993, p. 58-66; 1999, p. 478).

As repercussões desse reconhecimento para um ideal democrático de tolerância são fortes e evidentes, conformando um critério de razoabilidade para as pretensões que os cidadãos afirmam entre si e perante suas instituições políticas centrais ${ }^{52}$. Sendo livres e iguais - e igualmente sujeitos aos "limites da capacidade de juízo ou julgamento" -, cada um dos cidadãos detém um quinhão igual na autoridade política coletiva do Estado. Inexistem razões,

${ }^{51}$ Devo a formulação desse último período a uma sugestão de Álvaro de Vita. Em um contexto de discussão acerca da sobrevivência no tempo de modos de vida e concepções do bem em uma sociedade justa, ver o breve, mas iluminador, comentário que Rawls dedica a essa temática cara a Berlin na palestra 5 do Political liberalism (1999, p. 197 e nota 32).

52 Rawls destaca também as implicações do ponto para a noção de razão pública, assunto que não abordarei neste trabalho (1993, p. 58-9). 
portanto, hábeis a justificar que "qualquer cidadão, ou associação de cidadãos, deva ter o direito de usar o (...) [poder estatal]" para decidir questões fundamentais de justiça política guiado por suas convicções particulares (Rawls, 1993, p. 61-2), não necessariamente compartilhadas pelos demais. Há, igualmente, aqui, um critério de determinação da razoabilidade das diversas doutrinas e perspectivas emergentes no contexto de instituições livres - ou, nos termos de Forst, um argumento normativo para delimitar cláusulas de rejeição no espaço normativo da tolerância (2007, p. 1-2, 10 1). Nesse sentido, estão dentro do espaço permissível ou são razoáveis as perspectivas que reconhecem a igualdade moral e os "limites da capacidade de juízo", aceitando o "fato do pluralismo" e, em consequência, as liberdades fundamentais a eles associadas.

Da minha perspectiva, esse conjunto de ideias rawlsianas aponta trilhas para a síntese coerente dos conteúdos mais importantes, e de maior apelo moral, constantes dos dois modelos normativos esboçados de justificação da tolerância e da neutralidade, acolhendo uma ideia "depurada" de autonomia, esclarecendo as bases da justificação recíproca e introduzindo uma explicação consistente para a dimensão epistêmica vista como necessária ao argumento da tolerância (Forst, 2007, p. 11). Explorar essa trilha é um desafio para a agenda de pesquisas sobre o assunto.

\section{Referências}

APPIAH, Anthony (2008). Neutrality reconsidered. Disponível em: http://www. creum.umontreal.ca/IMG/doc/appiah.doc. Acessado em: 17 jun. 2013.

BARRY, Barry (1995). "John Rawls and the search for stability". Ethics, v. 4, n. 105 , p. 874-915.

DWORKIN, Ronald (2005). Uma questão de princípio. São Paulo: Martins Fontes.

FORST, Rainer (2007). Toleration. Disponível em: http://plato.stanford.edu/ entries/toleration/. Acessado em: $1^{\circ}$ jul. 2013.

GALEOTTI, Anna Elisabetta (2008). "Identity, difference, toleration", em DRYZEK, Jhon S.; HONIG, Bonnie \& PHILLIPS, Anne. The Oxford handbook of political theory. Oxford: Oxford University Press.

KYMLICKA, Will (1992a). "Liberal individualism and liberal neutrality", em AVINERI, Shlomo \& DE-SHALIT, Avner. Communitarianism and individualism. Oxford: Oxford University Press. 
(1992b). "Two models of pluralism and tolerance". Analyse \& Kritik, n. 13, p. 33-56.

MACEDO, Stephen (1995). “Toleration and fundamentalism”, em GOODIN, Robert \& PETTIT, Phillipe. A companion to contemporary political philosophy. Cambridge: Blackwell.

MENDUS, Susan (2008). "Impartiality", em DRYZEK, Jhon S.; HONIG, Bonnie \& PHILLIPS, Anne. The Oxford handbook of political theory. Oxford: Oxford University Press.

MILL, John Stuart (1988). Sobre a liberdade. Petrópolis: Vozes.

NAGEL, Thomas (1987). "Moral conflict and political legitimacy". Philosophy and public affairs, v. 16, n. 3, p. 215-40.

(1991). Equality and parciality. Oxford: Oxford University Press.

RAWLS, John (1971). A theory of justice. Cambridge (MA): Harvard University Press.

(1993). Political liberalism. New York: Columbia University Press.

(1999). Collected papers. Cambridge (MA): Harvard University Press.

RAZ, Joseph (1986). The morality of freedom. Oxford: Clarendon Press. SCANLON, Thomas (1982). "Contractualism and utilitarianism", em SEN, Amartya \& WILLIAMS, Bernard. Utilitarianism and beyond. Cambridge: Cambridge University Press.

(2003). The difficulty of tolerance. Cambridge: Cambridge University Press.

WALDRON, Jeremy (1993). Liberal rights: collected papers. Cambridge: Cambridge University Press.

WALZER, Michael (1999). Da tolerância. São Paulo: Martins Fontes. WILLIAMS, Melissa \& WALDRON, Jeremy (2008). "Introduction”, em Toleration and its limits. Nomos XLVIII. Disponível em: http//www. nyupress.org/webchapters/9780814794111_Williams_intro.pdf. Acessado em: $1^{\circ}$ jul. 2013.

\section{Resumo}

À luz das discussões normativas contemporâneas sobre a justiça, o artigo discute as noções de tolerância e de neutralidade e avalia, em termos éticos e político-institucionais, modelos de justificação da tolerância como "respeito mútuo". Examina-se, inicialmente em termos lógicos, o conceito de tolerância, transitando-se, em seguida, para concepções 
normativamente mais densas da noção. Após indicar a maior pertinência, no contexto de sociedades pluralistas, da concepção de tolerância como "respeito mútuo", insere-se na discussão a noção de neutralidade, endereçada às instituições políticas. Após rejeitar tentativas de ancorar a tolerância (e a neutralidade) em razões elas próprias neutras, do ponto de vista moral, o texto examina dois modelos de justificação - centrados nos valores da autonomia e da justificação razoável -, sugerindo-se a possibilidade de sua síntese a partir de perspectivas extraídas do liberalismo rawlsiano.

Palavras-chave: tolerância; neutralidade estatal; hard-choices; respeito mútuo; modelos de justificação.

\section{Abstract}

In light of contemporary normative arguments about justice, the paper discusses the notions of tolerance and neutrality, and evaluates, in ethical and political-institutional terms, models for justification of tolerance as "mutual respect". It examines, at first in logical terms, the concept of tolerance, then moving to normatively denser conceptions of the concept. After indicating greater relevance, in the context of pluralistic societies, of the concept of tolerance as "mutual respect", it incorporates the notion of neutrality into the discussion, addressed to political institutions. After rejecting attempts to anchor tolerance (and neutrality) on neutral grounds, from the moral point of view, the text examines two models of justification - focusing on the values of autonomy and reasonable justification -, suggesting the possibility of its synthesis from perspectives drawn from Rawlsian liberalism.

Keywords: tolerance, State neutrality; hard choices; mutual respect; models of justification.

Recebido em 10 de fevereiro de 2014. Aprovado em 24 de maio de 2014. 